\title{
Sciades herzbergii OXIDATIVE STRESS BIOMARKERS: AN IN SITU STUDY OF AN ESTUARINE ECOSYSTEM (SÃO MARCOS' BAY, MARANHÃO, BRAZIL)*
}

\author{
Raimunda Nonata Fortes Carvalho-Neta ${ }^{l}$ and Ana Lúcia Abreu-Silva ${ }^{2}$
}

${ }^{1}$ Universidade Estadual do Maranhão (UEMA)

Biotecnologia Programa de Pós-Graduação - Rede Nordeste de Biotecnologia - RENORBIO

Laboratório de Pesca, biodiversidade e dinâmica populacional de peixes. Departamento de Química e Biologia (Campus Paulo VI, Tirirical, 65000-000 São Luís, MA, Brasil)

E-mail: raimundafortes@yahoo.com.br

${ }^{2}$ Universidade Estadual do Maranhão (UEMA)

Biotecnologia Programa de Pós-Graduação - Rede Nordeste de Biotecnologia - RENORBIO

Laboratório de Patologia. Curso de Medicina Veterinária

(Campus Paulo VI, Tirirical, 65000-000 São Luís, MA, Brasil)

\section{A B S T R A C T}

In order to study the effects of environmental contamination on wild fish, sites were sampled in São Marcos' Bay. The first is located near the ALUMAR/ALCOA port, a potentially contaminated area. The second, located near the Coqueiro beach, was used as a reference area. The activity of antioxidant defence catalase (CAT) and glutathione S-transferase (GST) in S. herzbergii was compared with the biometric data and gonadosomatic index (GSI). The result showed that GSI decreased significantly in females $(\mathrm{p}<0.05)$ at the contaminated site. The activity of CAT was higher in fish caught at the contaminated site. A significant difference was observed in GST activity in the liver of $S$. herzbergii in the comparison between fish from the contaminated site and those from the reference site $(\mathrm{p}<0.05)$. GSI provides new insights into the nature of the detoxification response in this catfish species because it is not correlated with the enzymes at the potentially contaminated site. We are, therefore, in a position to suggest that the elevated GST/CAT activity might well be related to the reproduction of the animals at the reference site but not at the potentially contaminated site. If that be the case, one may conclude that GST/CAT and GSI are useful biomarkers of aquatic contamination.

\section{RESUMO}

O objetivo desse trabalho foi estudar os efeitos da contaminação ambiental em peixes amostrados em dois locais da Baía de São Marcos. O primeiro ponto está localizado próximo ao porto da ALUMAR/ALCOA, considerado como uma área potencialmente contaminada. O segundo ponto, situado na praia do Coqueiro, foi usado como uma área de referência. Dados da atividade da enzima de defesa antioxidante catalase (CAT) e da glutationa S-transferase (GST) em S. herzbergii foram comparados com os dados biométricos e o índice gonadossomático (GSI). Resultados mostraram que o GSI diminuiu significativamente em fêmeas $(\mathrm{p}<0.05)$ no local contaminado. A atividade da CAT foi mais alta nos peixes do local contaminado. Uma diferença significativa foi observada na atividade de GST de $S$. herzbergii no local contaminado e no local de referência ( $\mathrm{p}<0.05$ ). GSI possibilitou uma nova abordagem quanto à natureza da resposta de destoxificação nessa espécie de bagre porque este índice não apresentou correlação com as enzimas no local potencialmente contaminado, mas apresentou no local de referência. Assim, sugere-se que a boa correlação da GST/CAT e GSI poderia estar relacionada à reprodução dos animais no local de referência, mas não no local potencialmente contaminado. Se esse for o caso, pode-se concluir que GST/CAT e GSI podem ser utilizados como bons biomarcadores para avaliar contaminação aquática.

Descriptors: Glutathione S-transferase; Catalase; Gonadosomatic index; Catfish; Marine pollution. Descritores: Glutationa S-transferase; Catalase; Índice gonadossomático; Bagre; Poluição marinha. 


\section{INTRODUCTION}

Aquatic animals are exposed to chemical contamination by virtue of an increasing range of anthropogenic activities that may activate a variety of different toxicity mechanisms, each contributing in diverse ways to the overall deleterious effect (Correia et al., 2003)

São Marcos' Bay is an important fishing location and the most important port in the Maranhão State, receiving its water mainly from the Mearim River. In the last decade, biochemical contamination of this Bay due to sewage discharge and the nutrient runoff from farms, pesticides, industrial waste, as well as the incorrect use of resources and the introduction of new fish species, have all aggravated environmental impact, and thus led to an increasing threat to the health of aquatic organisms. The main pollutants, such as heavy metals, derive from industrial activities through their respective marine terminals (Itaqui and ALUMAR/ALCOA) located in São Marcos' Bay (Zoneamento Costeiro do Estado do Maranhão, 2003).

In this estuarine area, fishes are exposed to mixtures of pollutants, whose synergistic and antagonistic effects are interpreted and predicted exclusively by chemical analysis. There is no information on the levels of contaminants or the related biological responses of these organisms.

In biomonitoring, biomarker analysis has been considered adequate to ascertain the toxic effects of a given toxicant. The biomarkers have then been defined by measurable modifications at the molecular, biochemical, cellular, physiological and behavioral levels revealing the exposure of a given organism to xenobiotics (Depledge et al., 1995). In fishes, detoxification enzymes, stress proteins, steroid hormone levels, histological alterations and numerous other parameters have been widely used in field biomonitoring studies (Mayon et al., 2006). Exposure to xenobiotics usually causes changes both in enzyme expression and in function, providing parameters for the biochemical monitoring of the environment. Polluting substances such as heavy metals could act on the organisms by forming free radicals of oxygen, initiating degenerative processes and causing oxidative stress (Tagliari et al., 2004).

In accordance with Ogunji et al. (2007), the main antioxidative enzymes are the super-oxide dismutase (SOD), responsible for hastening the dismutation of $\mathrm{O}_{2}^{-}$to $\mathrm{H}_{2} \mathrm{O}_{2}$, the catalase (CAT) and glutathione peroxidase (GPx). The two latter enzymes are responsible for reducing $\mathrm{H}_{2} \mathrm{O}_{2}$ to $\mathrm{H}_{2} \mathrm{O}$, and are considered the most important antioxidant enzymes found in vertebrates. When the antioxidant defenses are insufficient to combat the action of the reactive oxygen species (ROS), the result is oxidative stress followed by the oxidation of lipids, proteins and DNA.

The glutathione $S$-transferases (GSTs) belong to a phase II detoxification enzyme family that can mitigate the cellular toxicity of a number of endogenous and environmental chemicals (Hayes and Pulford, 1995). Environmental chemicals detoxified by GSTs include carcinogens, pesticides, and reactive intermediates (Eaton and Bammler, 1999). Besides their role in biotransformation, GSTs display many other functions such as those of peroxidase- and isomerase-activities, protection against $\mathrm{H}_{2} \mathrm{O}_{2}$ induced apoptosis (Sheehan et al., 2001) and conjugating subproducts of the lipid peroxidation (Awashti et al., 2004).

This study focused on the defensive role of antioxidant enzymes against oxidative damage in Sciades herzbergii (Ariidae), a benthic species of catfish dwelling in estuarine waters of the Island of São Luís and which has had to adapt to alternating concentrations of dissolved oxygen and salinity. This catfish was selected because of its distribution throughout São Marcos' Bay, its tolerance to estuarine pollution and its medium size ensuring the necessary supply of biological material for assays. The objective is to evaluate the relationship between the biometric data of the Sciades herzbergii and activity of antioxidant defense catalase (CAT) and the phase II biotransformation enzyme glutathione S-transferase (GST) in the liver of this catfish in São Marcos' Bay.

\section{Material and Methods}

\section{Site Description and Sample Collection}

Specimens of Sciades herzbergii were caught at two sites in São Marcos' Bay. The first site (S1) is located near the ALUMAR/ALCOA port $\left(02^{\circ} 43^{\prime} 14^{\prime \prime} \mathrm{S}\right.$ and $\left.044^{\circ} 23^{\prime} 35^{\prime \prime} \mathrm{W}\right)$, a potentially contaminated area. The second site (S2), located near the Coqueiro beach (02'43'59' $S$ and $044^{\circ} 21^{\prime} 59^{\prime}$ ' $\mathrm{W}$ ), was used as a reference area based on the assumption that it would be free from contamination (Fig. 1).

The fish were collected in their natural habitats using gill nets, in August 2007. At the time of collection, salinity was $27 \mathrm{ppm}$ (S1) and $25 \mathrm{ppm}$ (S2), $\mathrm{pH}$ was 7.9 (S1) and 7.0 (S2), the water temperature was $28^{\circ} \mathrm{C}$ ( $\mathrm{S} 1$ and $\mathrm{S} 2$ ) and the air temperature $29^{\circ} \mathrm{C}$ (S1 and S2). The fish were killed by trans-spinal dissection and their livers were excised and immediately frozen in liquid nitrogen. The totality of the material was collected from 40 fish. The total length $\left(\mathrm{L}_{\mathrm{T}}\right)$, standard length $\left(\mathrm{L}_{\mathrm{S}}\right)$, fork length $\left(\mathrm{L}_{\mathrm{F}}\right)$, total weight $\left(\mathrm{W}_{\mathrm{T}}\right)$ and gonad weight $\left(\mathrm{W}_{\mathrm{G}}\right)$ of each fish were recorded. 


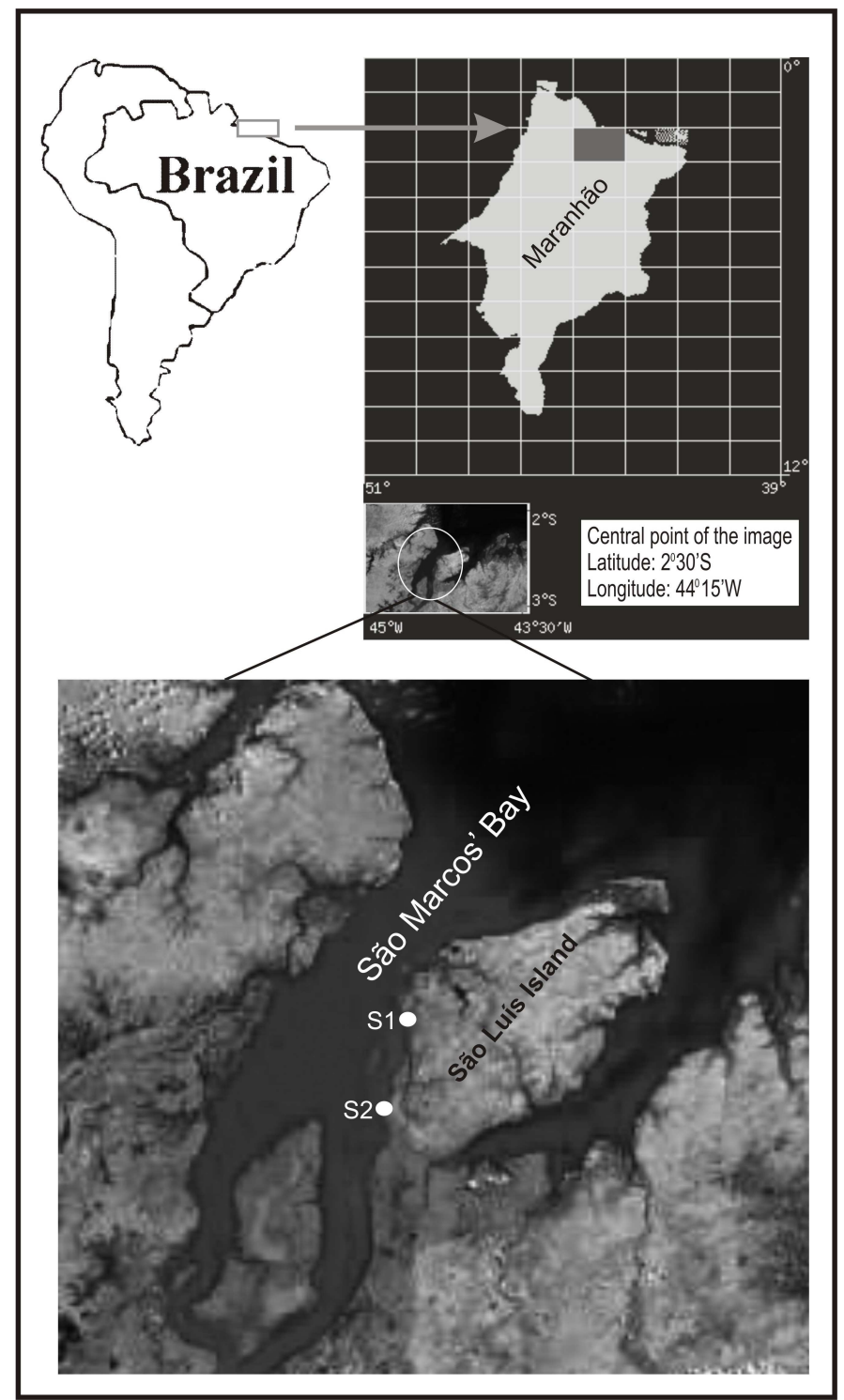

Fig. 1. Location of catfish sampling sites in São Marcos’ Bay: S1 (potentially contaminated); S2 (reference).

Gonadosomatic index (GSI) was calculated as follows: (gonad weight $\times 100) /$ total weight (Vazzoler, 1981).

\section{Tissue Processing and Biochemical Measurements}

The livers were weighed and homogenized with 1:4 vol. of buffer (Tris-HCl $50 \mathrm{mM}, 0.15 \mathrm{M} \mathrm{KCl}$, $\mathrm{pH}$ 7.4), and centrifuged at $9,000 \mathrm{x}$ g for $30 \mathrm{~min}$ at $4^{\circ}$ C. The supernatant fraction was centrifuged at 37,000 $\mathrm{x} g$ for $60 \mathrm{~min}$ at $4^{\circ} \mathrm{C}$, in order to obtain the cytosolic fraction. This latter was that used to analyze the activity of CAT and GST.
Protein concentration in the supernatants was determined in accordance with the modified method of Lowry using bovine serum albumin as standard (Peterson, 1977).

CAT activity was quantified at $240 \mathrm{~nm}$ by the $\mathrm{H}_{2} \mathrm{O}_{2}$ decomposition according to the method of Beutler (1975). The method is based on $\mathrm{H}_{2} \mathrm{O}_{2}$ degradation by the action of the CAT contained in the samples examined. One unit of enzyme activity is defined as the amount of enzyme which decreases the concentration of $\mathrm{H}_{2} \mathrm{O}_{2}$ by $50 \%$ in $100 \mathrm{~s}$ at $25^{\circ} \mathrm{C}$. The CAT activity is expressed as $\mathrm{U} / \mathrm{mg}$ protein. 
GST activity was determined by the increase in absorbance to $340 \mathrm{~nm}$, using reduced glutathione (GSH) and 1-chloro-2,4-dinitrobenzene (CDNB) as substrates, in accordance with Keen et al. (1976). The method is based on the reaction of CDNB to the -SH group of GSH catalyzed by the GST contained in the samples. The assay was conducted by monitoring the appearance of the conjugated complex of CDNB and glutathione at $340 \mathrm{~nm}$. The GST activity is expressed as $\mu \mathrm{mol} / \mathrm{min} / \mathrm{mg}$ protein.

\section{Statistical Analysis}

Significant differences between groups were verified using the t-test and one-way analysis of variance, and only $\mathrm{p}<0.05$ was accepted as significant. Linear correlation coefficients between enzymes (GST, CAT) and biometric data $\left(\mathrm{L}_{\mathrm{T}}, \mathrm{L}_{\mathrm{S}}, \mathrm{L}_{\mathrm{F}}, \mathrm{W}_{\mathrm{T}}, \mathrm{W}_{\mathrm{G}}\right.$ and GSI) were calculated using the mean values observed for each parameter.

\section{Results}

The results of the statistical analysis of the biometric data of Sciades herzbergii are presented in Table 1. The mean total and fork length of the fish caught at the potentially contaminated site were smaller than those from the reference site. The total body and gonad weight were not significantly different between the two sites. However, the gonadosomatic index showed significant differences $(\mathrm{p}<0.05)$ between the two fish groups (Table 2).

Table 1. Biometric data of Sciades herzbergii caught in São Marcos’ Bay, Maranhão, Brazil.

\begin{tabular}{|c|c|c|c|}
\hline \multirow[t]{2}{*}{ Parameters } & \multicolumn{2}{|c|}{ Mean \pm S.D. } & \multirow[t]{2}{*}{ t- test } \\
\hline & S1 & $\mathrm{S} 2$ & \\
\hline $\mathrm{L}_{\mathrm{T}}$ & $23.90 \pm 3.24(\mathrm{~cm})$ & $25.81 \pm 2.79(\mathrm{~cm})$ & 0.035 \\
\hline $\mathrm{L}_{\mathrm{F}}$ & $20.44 \pm 2.76(\mathrm{~cm})$ & $24.21 \pm 2.91(\mathrm{~cm})$ & 0.006 \\
\hline $\mathrm{W}_{\mathrm{T}}$ & $108.14 \pm 47.10(\mathrm{~g})$ & $143.35 \pm 57.24(\mathrm{~g})$ & 0.626 \\
\hline $\mathbf{W}_{\mathbf{G}}$ & $0.625 \pm 0.377(\mathrm{~g})$ & $0.934 \pm 0.363(\mathrm{~g})$ & 0.652 \\
\hline
\end{tabular}

Table 2. Gonadosomatic index of Sciades herzbergii caught in São Marcos' Bay, Maranhão, Brazil.

\begin{tabular}{|c|c|c|c|}
\hline \multirow[t]{2}{*}{ Gender } & \multicolumn{2}{|c|}{ Mean \pm S.D. } & \multirow[t]{2}{*}{ t- test } \\
\hline & $\mathrm{S} 1$ & S2 & \\
\hline Female & $0.82 \pm 0.52$ & $2.08 \pm 0.22$ & 0.025 \\
\hline Male & $0.23 \pm 0.03$ & $0.59 \pm 0.02$ & 0.041 \\
\hline
\end{tabular}

Greater CAT activity (Fig. 2) was observed in the liver of Sciades herzbergii from the potentially contaminated site than in those from the reference site $(\mathrm{p}<0.05)$.

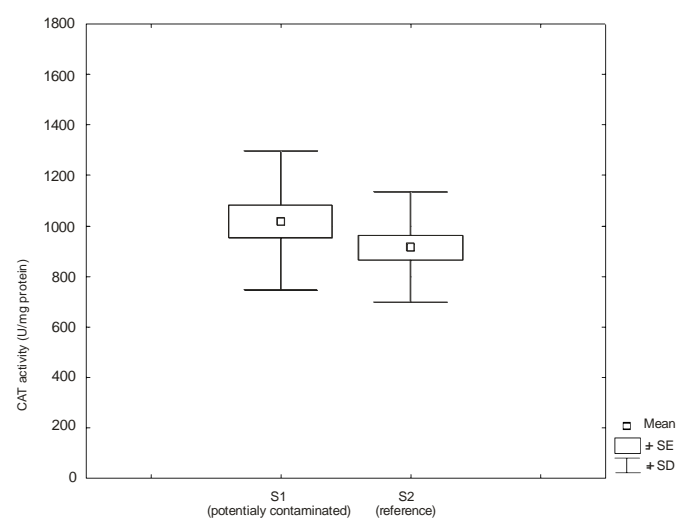

Fig. 2. Analysis of catalase activity in livers of Sciades herzbergii caught in São Marcos' Bay, Maranhão, Brazil.

Significant differences of GST activity $(p<0.05)$ were found between the livers of Sciades herzbergii caught at the potentially contaminated site (S1) and those caught at the reference site (S2), in São Marcos' Bay (Fig. 3). An increase of $10 \%$ was observed in the GST activity of the S1 fish $(2.19 \pm$ $0.37 \mu \mathrm{mol} / \mathrm{min} / \mathrm{mg}$ protein) over that of the animals at $\mathrm{S} 2(1.97 \pm 0.27 \mu \mathrm{mol} / \mathrm{min} / \mathrm{mg}$ protein$)$.

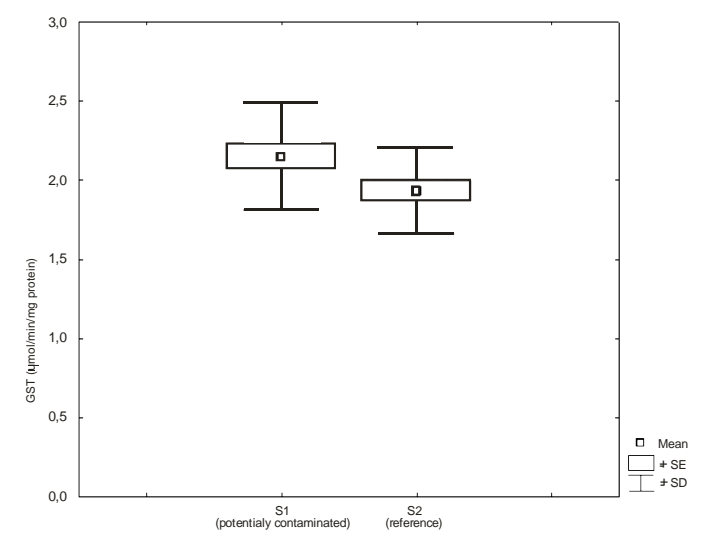

Fig. 3. Analysis of glutathione S-transferase activity in liver of Sciades herzbergii caught in São Marcos’ Bay, Maranhão, Brazil.

The data on GST and CAT activity in the livers of $S$. herzbergii (males and females) are summarized in Figure 4. GST and CAT values did not appear to be sex-dependent ( $p>0.05$ ). No significant changes were observed in these enzymes when the animals from each site were analyzed and compared. However, both males and females caught at the potentially contaminated site presented significantly higher GST/CAT activity. 

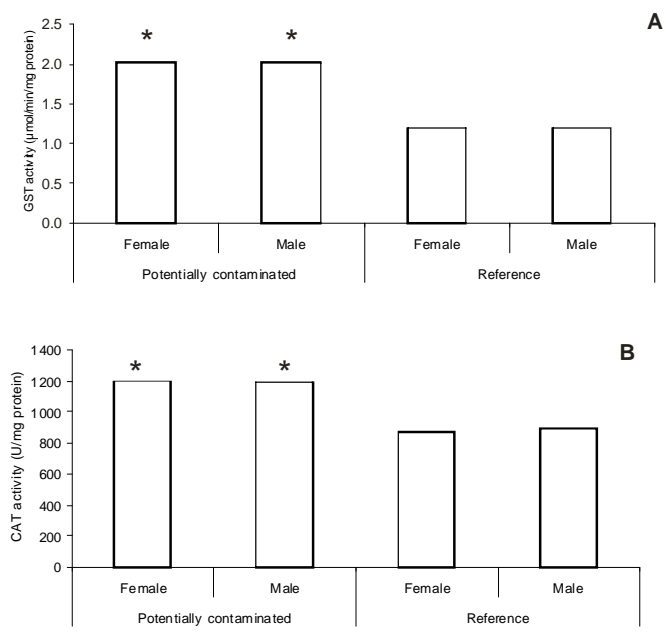

Fig. 4. Analysis of glutathione S-transferase (A) and catalase (B) activity in the livers of Sciades herzbergii (males and females) caught in São Marcos’ Bay, Maranhão, Brazil.

A significant negative correlation was observed between the GST activity and the $\mathrm{L}_{\mathrm{F}}$ parameter in fishes at the potentially contaminated (S1) and reference sites (S2) in São Marcos' Bay (Table 3). A similar correlation was observed between CAT activity and the $\mathrm{L}_{\mathrm{F}}$. However, a significant correlation between GSI and the activity of the two enzymes was only observed at the reference site (Table 3).

\section{Discussion}

The biomarkers associated with the biometric data results showed significant differences between the reference area and the potentially contaminated site studied in São Marcos' Bay. Comparative studies of biochemical indicators of contaminant exposure in spotted pigfish (Orthopristis ruber) caught in three bays on the Rio de Janeiro coast showed that biometric data (total length, weight) in those fishes could be a factor affecting the biochemical analyses such as the activity of the antioxidant defence catalase and the phase II biotransformation enzyme glutathione S-transferase (Ventura et al., 2002).

Such xenobiotics cause disruption of the reproductive endocrine system in fishes, or they may directly affect gamete development and viability as a result either of their cytotoxicity or by altering the hormonal environment during gamete development (Kime, 2000). The GSI in fish from the potentially contaminated site (São Marcos' Bay) was significantly lower $(\mathrm{p}<0.05)$ than in control fish during all the phases of the gonadal cycle. Most studies have shown a decrease in the gonadosomatic index (GSI) in contaminated fishes (Mayon et al., 2006). This decrease in the index can result in abnormal gonadal development in the form of delayed maturation, high levels of atresia or intersexuality (Kime, 1998). Previous studies on sediment and water contamination in the area studied showed significantly higher levels of mercury and chrome which confirms that São Marcos' Bay is a site with high exposure risks for some contaminants (LABOHIDRO/UFMA, 1985; Cavalcante et al., 1990).

Considering that CAT is mainly located in the peroxisomes, and is responsible for the reduction of the hydrogen peroxide produced in larger amounts during the biotransformation process (Winston and Di Giulio, 1991), our results could suggest that a prooxidant condition elicited by the presence of contaminants in S2 might be triggering an increase in the activity of this antioxidant enzyme, as an adaptive response. A similar study carried out by Ventura et al. (2002) showed that higher CAT activity in fish from Guanabara Bay, might be related to the presence of greater amounts of peroxisome proliferators at that site.

Table 3. Linear correlation between the CAT/GST activity and the biometric data $\left(\mathrm{L}_{\mathrm{T}}, \mathrm{L}_{\mathrm{S}}, \mathrm{L}_{\mathrm{F}}, \mathrm{W}_{\mathrm{T}}, \mathrm{W}_{\mathrm{G}}\right.$ and GSI) of Sciades herzbergii in São Marcos' Bay.

\begin{tabular}{|c|c|c|c|c|c|c|}
\hline & $L_{T}$ & $L_{S}$ & $L_{F}$ & $W_{T}$ & $W_{G}$ & $G S I$ \\
\hline \multirow[t]{2}{*}{ GST (S1) } & $r=-0.3184$ & -0.3230 & -0.8689 & -0.3271 & -0.2214 & -0.1698 \\
\hline & $\mathrm{p}=0.036$ & $\mathrm{P}=0.036$ & $\mathrm{p}=\mathbf{0 . 0 1 1}$ & $\mathrm{p}=0.043$ & $\mathrm{p}=0.040$ & $\mathrm{p}=0.041$ \\
\hline \multirow[t]{2}{*}{ GST (S2) } & $\mathrm{r}=-0.2422$ & -0.1932 & -0.7690 & -0.2394 & -0.5886 & -0.8599 \\
\hline & $\mathrm{p}=0.039$ & $\mathrm{P}=0.013$ & $\mathrm{p}=\mathbf{0 . 0 4 3}$ & $\mathrm{p}=0.040$ & $\mathrm{p}=0.041$ & $p=0.036$ \\
\hline \multirow[t]{2}{*}{ CAT (S1) } & $r=0.2393$ & 0.2860 & -0.8922 & -0.1713 & -0.1924 & -0.2516 \\
\hline & $\mathrm{p}=0.068$ & $\mathrm{P}=0.427$ & $\mathrm{p}=\mathbf{0 . 0 0 2}$ & $\mathrm{p}=0.794$ & $\mathrm{p}=0.166$ & $\mathrm{p}=0.011$ \\
\hline \multirow[t]{2}{*}{ CAT (S2) } & $r=-0.1749$ & -0.1751 & -0.7168 & -0.0181 & -0.5320 & -0.7331 \\
\hline & $\mathrm{p}=0.428$ & $\mathrm{P}=0.327$ & $\mathrm{p}=\mathbf{0 . 0 0 2}$ & $\mathrm{p}=0.594$ & $\mathrm{p}=0.266$ & $p=0.016$ \\
\hline
\end{tabular}


Glutathione S-transferase activity in the livers of Sciades herzbergii showed a significant response to oxidative stress at the contaminated site in São Marcos' Bay, possibly related to a higher level of contamination. In a general way, it was observed that the smaller and lighter the animal was, the greater the activity of GST, indicating a possible susceptibility of the youngest and sexually immature fish to oxidative stress in the area analyzed. Young fish would have been more affected than adults, probably due to gonadal development and the habitat difference between juveniles and older individuals.

The activity of the detoxification enzymes differs among the organs and tissues of marine fish, depending upon feeding behavior, age, gonadal development, environmental factors and other ecological conditions (Winston and Di Giulio, 1991). This was particularly the case regarding the age of the animals and their endocrine parameters since the hormonal status of fish is highly variable during the reproductive period, depending on the environmental conditions of the station. In São Marcos' Bay a significant negative correlation was observed between the GST/CAT activity and the $\mathrm{L}_{\mathrm{F}}$ parameter in all fishes, but a significant correlation between GSI and the activity of the two enzymes was only observed in organisms from the reference site. Fork length $\left(\mathrm{L}_{\mathrm{F}}\right)$ in catfish was reported to be a good predictor of age for individuals of this species (Penha et al., 2004). We may, therefore, hypothesize that the elevated GST activity might be related to the age of the animals in São Marcos' Bay (at both the reference and potentially contaminated sites).

GSI provides new insights into the nature of the detoxification response in Sciades herzbergii because it is not correlated with the enzymes at the potentially contaminated site. However, additional biomonitoring is needed to validate the use of GST/CAT correlated with GSI as biomarkers of aquatic contamination in the natural environment, rather like seasonal adjustments in the antioxidant defence.

The use of GST/CAT associated with biometric data in this study enhances our understanding of the Sciades herzbergii in situ as demonstrating its great suitability in the monitoring of estuarine areas.

\section{Conclusion}

The present study shows that: (1) Sciades herzbergii has demonstrated its great suitability for monitoring estuarine areas, especially on the basis of oxidative stress and the gonadosomatic index; (2) GST/CAT activity might be related to the reproduction of the animals at the reference site but not at the potentially contaminated site. Additional biomonitoring to determine agonistic or antagonistic effects of xenobiotics on the GST and CAT activity of Sciades herzbergii are needed to validate the use of GST/CAT correlated with GSI as biomarkers of aquatic contamination in the natural environment.

\section{AcKNOWLEDGEMENTS}

We would like to acknowledge Dr. Afonso Celso Dias Bainy, Juliano Zanette (Departamento de Bioquímica, Universidade Federal de Santa Catarina, Florianópolis, Brazil) and Dr. Audalio Rebelo Torres Jr. (Laboratório de Modelagem de Processos Marinhos e Atmosféricos, Universidade Federal do Rio de Janeiro) for their invaluable help with the biochemical and statistical analysis. Thanks are also due to Antonio Poca, Marcelino Silva Farias and Marcelino Silva Farias Filho for their help during the fish sampling.

\section{REFERENCES}

AWASHTI, Y. C.; YANG, Y. S.; TIWARI, N. K.; PATRICK, B.; SHARMA, A.; LI, J., AWASTHI, S. Regulation of 4-hydroxynonenal-ediated signaling by glutathione S-transferases. Free Radic. Biol. Med. v. 37, p. 607-619, 2004.

BEUTLER, E. Red cell metabolism: a manual of biochemical methods. New York: Grune \& Straton, 1975.

CAVALCANTE, P. R. S.; TAROUCO, J. E. F.; COSTA, M. L. Avaliação dos níveis de mercúrio da porção interna do Golfão Maranhense. In: FINEP. Riscos e consequiências do uso do mercúrio. Brasília: FINEP, 1990. p. 314.

CORREIA, A. D.; COSTA, H. M.; LUIS, O. J.; LIVINGSTONE, D. R. Age-related changes in antioxidant enzyme activities, fatty acid composition and lipid peroxidation in whole body Gammarus locusta (Crustacea: Amphipoda). J. Exp. Mar. Biol. Ecol., v. 289 , p. 83-101, 2003.

DEPLEDGE, M. H.; AAGAARD, A.; GYORKOS, R. Assessment of trace metal toxicity using molecular, physiological and behavioural biomarkers. Mar. Pollut. Bul., v. 31, p. 19-27, 1995.

EATON, D. L.; BAMMLER, T. K. Concise review of the glutathione

$S$-transferases and their significance to toxicology. Toxicol. Sci., v. 49, p. 156-164, 1999.

HAYES, J. D.; PULFORD, D. J. The glutathione $S$ transferase supergene family: regulation of GST and the contribution of the isoenzymes to cancer chemoprotection and drug resistance. Crit. Rev. Biochem. Mol. Biol., v. 30, p. 445-600, 1995.

KEN, J. H.; HABIG, W. H.; JAKOBY, W. B. Mechanism for several activities of the glutathione S-transferases. J Biol Chem, v. 251, p. 6183-6188, 1976.

KIME, D. E. Endocrine disruption in fish. MA: Kluwer Academic Publishers, 1998. p. 325-396

KIME, D. E. A strategy for assessing the effects of xenobiotics on fish reproduction. MA: Kluwer Academic Publishers, 2000. p. 20-28. 
LABOHIDRO/UFMA. Levantamento bioecológico na área de influência da Indústria de Alumínio do Consórcio ALUMAR na Ilha de São Luís - Maranhão. São LuísMA: ALUMAR, 1985. 65 p.

MAYON, N.; BERTRAND, A.; LEROY, D.; MALBROUCK, C.; MANDIKI, S. N. M.; SILVESTRE F.; THOMÉ, J. P.; KESTEMONT, P. Multiscale approach of fish responses to different types of environmental contaminations: A case study. Scien. of the Total Environ., v. 367, p. 715-731, 2006.

OGUNJI, J.; NIMPTSCH, J.; WIEGAND, C.; SCHULTZ, C. Evaluation of the influence of housefly maggot meal (magmeal) diets on catalase, glutathione S-transferase and glycogen concentration in the liver of Oreochromis niloticus fingerling. Comp. Biochem. and Physiol., Part A, v. 147, p. 942-947, 2007.

PENHA, J. M. F.; MATEUS, L. A. F.; BARBIERI, G. Age and growth of the porthole shovelnose catfish (Hemisorubim platyrhynchos) in the Pantanal. Braz. J. Biol. [online]. v. 64, n. 4 [cited 2007-12-06], pp. 833 840, 2004.

PETERSON, G. L. A simplification of the protein assay method of Lowry et al. which is more generally applicable. Anal Biochem., v. 83, p. 346-56, 1977.

SHEEHAN, D.; MEADE, G.; FOLEY, V.M.; DOWD, C.A. Structure, function and evolution of glutathione transferases: implications for classification of nonmammalian members of an ancient enzyme superfamily. Biochem. J., v. 360, p. 1-16, 2001.
TAGLIARI, K. C.; CECCHINI, R.; ROCHA, J. A. V.; VARGAS, V. M. F. Mutagenicity of sediment and biomarkers of oxidative stress in fish from aquatic environments under the influence of tanneries. Mutat. Res., v. 561, p. 101-117, 2004.

VAZZOLER, A. E. A. DE M. Manual de métodos para estudos biológicos sobre populações de peixes: crescimento e reprodução. Brasília: $\mathrm{CNPq} /$ Programa Nacional de Zoologia, 1981. p. 15-25.

VENTURA, E. C.; GAELZER, L.R.; ZANETTE, J.; MARQUES, M.R.F.; BAINY, A.C.D. Biochemical indicators of contaminant exposure in spotted pigfish (Orthopristis ruber) caught at three bays of Rio de Janeiro coast. Mar Environ Res., v. 54, p. 775-779, 2002

WINSTON, G.W.; DI GIULIO, R.T. Prooxidant and antioxidant mechanisms in aquatic organisms. Aquat. Toxicol., v. 19, p. 137-161, 1991.

Zoneamento Costeiro do Estado do Maranhão. 2003. Fundação Sousândrade de apoio do desenvolvimento da Universidade Federal do Maranhão/Departamento de Oceanografia e Limnologia, DEOLI/Laboratório de Hidrobiologia - LABOHIDRO, Núcleo Geoambiental UEMA. 2 CD-ROM.

(Manuscript received 24 June 2009; revised 26 January 2010; accepted 05 March 2010) 